\title{
The Role of Institutional Determinants in Attracting Foreign Direct Investment to Egypt: Empirical Study
}

\author{
Bahy Mohamed Yassin and Fakhry Elfiky \\ Benha University, Egypt
}

\author{
Nadia El Nimer \\ Cairo University, Egypt
}

This paper aims to explore the relationship between foreign direct investment (FDI) in Egypt, as a dependent variable, and selected economic and institutional determinants for the period (1996-2018). The work attempts to bridge the gap created by previous empirical literature that failed to focus on critical institutional determinants of FDI in developing countries, especially governance-related determinants. The study used the autoregressive distributed lag model (ARDL); to test the Cointegration relationship between FDI and its determinants. Besides, the error correction model (ECM) was used to explore the short-run relationship. In light of applying the ARDL approach, the study concluded that while both market size and regulatory quality stimulated FDI, the latter has been negatively affected by the real exchange rate and government effectiveness. Moreover, the study revealed that in the shortrun, both regulatory quality and control of corruption induced FDI in Egypt. These findings shed light on the crucial role that institutional factors can play in creating a more favorable FDI climate in Egypt.

Keywords: foreign direct investment, Egypt, economic determinants, institutional determinants,

JEL Classification: E44, F31, G15

According to UNCTAD, it is well-noted that FDI flows to developing countries (\% of global FDI flows) have risen over the 1990 s and 2000 s to hit an average of $30.6 \%$ and $31.6 \%$, respectively, compared to $25.2 \%$ in the 1980 s. Despite the 2008-2009 global financial crisis, the share of developing countries in the global FDI increased dramatically to $45.6 \%$ in 2010 with an increase of about 6.5 and 6.2 percentage points compared to 2008 and 2009, respectively. For the first time, the share of developing countries in total FDI exceeded that of developed countries registered $48.2 \%$, in

Correspondence concerning this article should be addressed to Mr. Bahy Mohamed Yassin, Doctoral Student, Faculty of Economics and Political Science, Cairo University, Egypt, Email: byassin429@gmail.com

Contribution of Authors:

1. Bahy Mohamed Yassin/ writing the original draft; preparation, writing, review and editing; Validation \& Conceptualization.

2. Fakhry Elfiky/ review and editing.

3. Nadia El Nimer/ review and editing. 
2018. Despite this share retreated to $44.5 \%$ in 2019 , developing countries and transition economies together received $48 \%$ of total FDI compared to $52 \%$ for developed countries in the same year (UNCTAD, 2020).

Such an increase in FDI flows to developing countries enabled these countries to focus on FDI in financing the development process (Akyüz \& Cornford, 2000). Consequently, rivalry among these countries increased simultaneously with the implementation of friendly and attractive policies, such as establishing economic zones, providing incentives to foreign investors and liberalizing trade regimes. As an example to the positive impact of this approach 35 countries adopted 82 FDI-related reforms aimed at attracting an increased flow of FDI in 1991 (Mottaleb, 2007).

Egypt, along with other developing countries, competes to attract both foreign and Arab capital. It sought to create a supportive investment climate by adopting an economic openness policy that mainly targets accelerated growth rates and provides guarantees, incentives, and concessions. Since then, the FDI has started appearing as one of the general items in the balance of payments within the balance of capital transactions (Ministry of Economy and Foreign Trade, 2000).

In addition, Egypt introduced an economic reform program in 1991 which aimed to resolve long-lasting structural imbalances. This program focused on ensuring the path towards market forces, encouraging individual initiatives, supportive policies to attract foreign investments, and continuing to liberalize the economy (Shabana, 1994). These reforms, accompanied by increasing FDI flows to Egypt from USD 253 million in 19991 to USD 636 and USD 1200 million in 1996 and 2000, respectively. Those flows fluctuated over the next period, ranging from USD 237 million in 2003 to USD 6.4 billion in 2010. Similarly, net FDI inflows recorded -483 million USD in 2011, followed by an increase to 4.6 and a peak of 8.1 billion USD in 2012 and 2016, respectively. Those flows retreated to USD 7.4 billion in 2017 and USD 6.8 billion in 2018 (UNCTAD, 2020).

Theoretically, before the 1960s, there was no theory for interpreting Multinational Enterprise activities or FDI. The first contribution belongs to Hymer 1960 and 1968, who criticized the traditional theory "international movements of indirect investment" which interpreted portfolio investments movements across borders as a result of differential rates of return between host countries (Basyouny, 1986; Dunning \& Lundan, 2008).

In contrast to the previous theory which adopted the hypothesis of perfect competition, recent ones have supposed imperfect competition as a necessary condition for Multinational Enterprises to maximize profits as well as minimize risks and uncertainty. Hymer presented the first theory in this context, called the theory of industrial enterprise (Dunning \& Lundan, 2008). This theory suggests that the decision of a company to invest abroad is motivated by two incentives. The first relates to the aim of maximizing profit on owned advantages, ownership advantages, or monopolistic advantages, such as marketing, financial, and innovation, as well as cost-related advantages. Such advantages help the enterprise to compete with other enterprises in the host countries where the production takes place. The second motive is linked to the MNE's effort to reduce or eradicate the international competition between enterprises (Hosseini, 2005; Dunning \& Lundan, 2008). In some situations, MNE create market imperfection by isolating foreign markets and eliminating competition to seize an opportunity (Dunning \& Rugman, 1985). 
The second theory was introduced by Vernon (1966), using a microeconomics concept, namely "the product cycle" to explain macro phenomenon "foreign activities of American MNEs post War". Vernon split the product cycle into three main phases: (a) the New product phase, where the product is not standardized with respect to its inputs, processes, and final features. In this stage the product is introduced into the mother country's local market, close to innovative activities and/or the markets (Vernon, 1966; Dunning \& Lundan, 2008). (b) The maturing product: here the degree of product standardization decreases with rising demand for the product. In addition, manufacturing the product based on the use of technology allows achieving economies of scale. Furthermore, the product started to be produced in the countries with an income level similar to that of the country that owns the investment. If the income elasticity on that product is high in the importing countries, the production of this product will move to these countries when the total of marginal cost and transportation cost is lower than the average cost of producing that product in those countries (Vernon, 1966). (c) The standardized product, in this phase, the product reaches a high standardization level. Moreover, investors are seeking to manufacture the product from the optimum locations, where the costs are minimized (Vernon, 1966).

The third theory is the internal use of monopolistic advantages. According to this theory, the MNEs use the monopolistic advantages they have to conquer the barriers the host countries have imposed. Particularly the regulations and controls that contradict free trade and FDI at a global level (Markusen, 1998; Rugman, 2006).

The fourth theory is the location theory introduced by Dunning. The FDI is created as a result of the immobility of certain factors of production, such as labor and natural resources. For this reason, the costs of production varies from one location to another. A main spatial cost determinant of FDI is labor cost while energy prices, closeness to raw materials, and capital costs are other costs that the investor considers when deciding to invest in one place (Moosa, 2002).

The fifth theory is the Eclectic theory. This theory is a comprehensive theory that incorporates the theory of industrial organization, the theory of using monopolistic advantages internally, and the location theory. Dunning introduced this theory to answer the question of why investments that belong to a particular country occur in another one. The investment stock and its change over time are a function of three combined terms: (a) ownership of monopolistic advantages against the firms from other nationalities when serving a single market. (b) The ability to use these advantages internally, rather than giving foreign firms the rights to use these advantages through licensing, management contracts, and franchise. (c) Location advantages that are immobile determine location profitability in a host country relative to that of the home country (Dunning 1979, 1981).

Since the FDI plays a key role in financing development as well as being an important instrument for transferring technologies and skills from mother countries to host ones, several empirical studies attempted to determine the factors that influence FDI. Table (1) in the appendix, shows that the applied studies that covered the factors that influenced the FDI flows to developed and developing countries were divided into a prominent pattern concentrating on economic determinants. Conversely, a few studies focused on institutional determinants. In this context, the majority of studies that dealt with FDI determinants in host countries focused on a collection of traditional quantitative economic factors. Researchers, however, have increasingly found that FDI is highly affected by the factors that are linked to the host country's transaction costs and constitute 
what is known as "the investment climate" (Kahai, 2004). Similar to the above case, Table (2) in the appendix, indicates that the institutional factors of FDI flows in Egypt have been addressed by very few empirical studies. Furthermore, these studies did not shed light on important aspects of the quality of institutions in Egypt (for example, governance-related factors, including the quality of regulations and procedures "as a proxy for doing business environment", control of corruption, and government effectiveness). Those factors are the cornerstone of the investment environment. According to Hassan (2008), one of the most vital factors affecting investment decision is the efficiency of institutions which serve investors and facilitate procedures and transactions. Consequently, neglecting to tackle previous factors in applied studies that considered the determinants of FDI in Egypt reflects the research gap that the study aims to bridge. Bridging this gap is a real addition to the literature on the FDI climate in Egypt, particularly the institutional side that has long been neglected in the literature.

As local savings are inadequate to cover the required investments to Egypt's development process, there is a great need to attract as many FDI flows as possible as one of the external sources of development financing. Therefore, in determining the factors shaping the FDI environment in Egypt, the importance of this study has been revealed by testing a combination of economic and institutional factors not previously used together in studies applied to Egypt, using annual data for the period (1996-2018). In addition, the study proposes a set of applicable recommendations to help decision-makers adopt sound economic and institutional policies that enhance Egypt's attractiveness to FDI and encourage local investment. These policies, which are based on a real institutional reform, help the government to successfully implement the second phase of reforms known as "the structural reforms" aimed at supporting certain sectors and increasing the competitiveness of the Egyptian economy.

\section{The Study Problem: Key Question, Goals and Hypothesis}

Despite FDI flows to Egypt increased significantly over the period (1996-2018), FDI flows to Egypt (as a percentage of global FDI, developing countries, lower-middle-income countries, and Africa) are still lower than the potential of the Egyptian economy. For example, FDI flows to Egypt accounted for only $0.52 \%$ of global FDI in 2018. In the same year, Egypt received $0.96 \%, 5.15 \%$, and $14.4 \%$ of FDI flows to developing countries, lower-middle-income, and Africa, respectively (UNCTAD, 2020). Moreover, FDI in Egypt is mainly concentrated in the petroleum sector. This concentration reflects a distortion in the sectoral distribution of FDI. The data shows that the petroleum sector accounted, on average, for $60.8 \%$ of the gross inward FDI to the economic activities over the period (2006/7-2017/18) compared to $6.4 \%$ for industry and agriculture together over the same period. Furthermore, the petroleum sector received, on average, $36.8 \%$ of the net FDI flows to Egypt over the period (2004/5-2018/19) (Shamoun, 2009; CBE, 2014/15-2017/18; Institute of National Planning, 2018a; CBE, 2019).

The study seeks to answer the following question. What are the key economic and institutional factors that have an impact on FDI flows to Egypt?. Accordingly, the study aims at testing and interpreting the influence of the selected group of variables that have never been used in the Egyptian case during the period (1996-2018) on FDI flows to Egypt. The study, therefore, tests two key hypotheses: (a) there is a significant relationship between FDI, as an explained variable, and its 
economic determinants over the period (1996-2018). (b) There is a significant relationship, over the same period, between FDI, as a predicted variable and its institutional determinants.

\section{Method}

In order to test the two hypotheses of this study, we used a Cointegration time series analysis using the Autoregressive Distributed Lag Model (ARDL), as one of the most popular dynamic regression models in econometric literature. Unlike the traditional Cointegration models (EngleGranger and Johansen), which requires the time series to be of the same order. The ARDL allows to use time series of different orders less than two. In addition, this model provides precise results, particularly with the short time series, and helps us to interpret long-run and short-run relationships (Pesaran et al., 2001; Hasan \& Showman, 2013). The ARDL technique also follows general to specific approach. Hence it could tackle several econometric problems (e. g. Endogeneity problem, serial autocorrelation, and mis-specification), and come up with a better interpretable model (Ghouse et al., 2018). It is worth noting that the existence of a long-run relationship between the variables ensures an adjustment mechanism that prevents the size of errors from being large. According to Engle and Granger (1987), the time series Co-integration is a necessary condition for the existence of an error correction mechanism, or for the expression of the relationship between those time series through the Error Correction Model (ECM) (Charemza \& Deadman, 2002). In light of the previous section, we propose an estimation model as follows:

$$
\begin{aligned}
& \Delta l \text { ldi }_{t}=\beta_{0}+\beta_{1} \text { lfdi }_{t-1}+\beta_{2} \text { lgdppcgr }_{t-1}+\beta_{3} \text { linfra }_{t-1}+\beta_{4} \text { lrexc }_{t-1}+\beta_{5} \text { lcc }_{t-1}+\beta_{6} \text { lgovef }_{t-1}+\beta_{7} \text { lrq }_{t-1} \\
& +\sum_{i=1}^{p} \gamma_{1} \Delta \text { lfdi }_{t-1}+\sum_{i=1}^{q_{1}} \gamma_{2} \Delta \text { lgdppcgr } \boldsymbol{t}_{t-i}+\sum_{i=1}^{q_{2}} \gamma_{3} \Delta \text { linfra } \boldsymbol{l i n}_{t-i}+\sum_{i=1}^{q_{3}} \gamma_{4} \Delta \text { lrexc }_{t-i} \\
& +\sum_{i=1}^{q_{4}} \gamma_{5} \Delta l c c_{t-i}+\sum_{i=1}^{q_{5}} \gamma_{6} \Delta \text { lgovef }_{t-i}+\sum_{i=1}^{q_{6}} \gamma_{7} \Delta l r q_{t-i}+\varepsilon_{t}
\end{aligned}
$$

Where the dependent variable (fdi), denotes net fdi flows to Egypt (\% of GDP). The explanatory variables expected to influence FDI flows to Egypt are carefully chosen, based on previous literature review and the data set availability, for the period (1996-2018). The independent variables used in the estimation divided into two equal main groups. The economic determinants represented in GDP per capita growth "gdppcgr" as a proxy for market size, public investments (\% of GDP) "infra" as a proxy for infra-Structure, and real exchange rate "rexc". The institutional determinants represented in control of corruption "cc", government effectiveness "govef", and regulatory quality " $r q$ " as a proxy for doing business. $\boldsymbol{p}$ denotes the number of lagged periods for the predicted variable. $\left(\boldsymbol{q}_{\mathbf{1}}-\boldsymbol{q}_{\mathbf{6}}\right)$ denote the number of lagged periods for the independent variables. $\boldsymbol{\beta}_{\boldsymbol{s}}$ denote the long-run coefficients and $\gamma_{s}$ refer to short-run coefficients.

The required data set was obtained from the World Bank dataset "WDI \& Worldwide Governance Indicators" for the variables fdi, gdppcgr, infra, cc, govef, and rq. While the data for rexc was obtained from both the World Bank "WDI" and IMF "IFS", and calculated based on the formula of Khalek (1998). The logarithm has been used to reduce the impact of big values and allow us to interpret the results as elasticity (Mohamed, 2010). The formula of (Busse \& Hefeker, 2006) were used to transform the data for the variables fdi, gdppcgr, cc, and govef. The Eviews was used to generate missing data for the years 1997, 1999, and 2001 relating to the variables cc, govef, and rq.

\section{Pre-estimation steps}

Investigating the normal distribution of data: As a pre-requisite before running the estimation, we must ensure that the data is normally distributed. Table (1), explores that the 
probability values of Jarque-Bera statistic for all variables are more than the $5 \%$ significance level. As a result, the data for all variables follows the normal distribution. This result supports the statistical use of these data in the estimation.

\section{Table 1}

\begin{tabular}{lccccccc} 
Descriptive Statistics \\
\hline \multicolumn{1}{l}{ LFDI } & LGDPPCGR & LINFRA & LREXC & LCC & LGOVEF & LRQ \\
\hline Mean & 1.3866 & 1.4336 & 2.1401 & 4.4214 & -0.5585 & -0.4489 & 3.5143 \\
Median & 1.2000 & 1.6845 & 2.1644 & 4.5099 & -0.5671 & -0.3956 & 3.6045 \\
Maximum & 2.9306 & 2.3635 & 2.7175 & 4.6580 & -0.3987 & -0.2160 & 3.9752 \\
Minimum & -0.2031 & -0.3563 & 1.6399 & 4.0320 & -0.7162 & -0.7919 & 2.8511 \\
Std. Dev. & 0.8018 & 0.8017 & 0.3008 & 0.2005 & 0.0867 & 0.1806 & 0.3293 \\
Skewness & 0.2806 & -0.9492 & 0.2068 & -0.6043 & -0.0612 & -0.5127 & -0.7992 \\
Kurtosis & 2.6060 & 2.8125 & 2.6855 & 1.9970 & 2.2382 & 2.0526 & 2.6795 \\
Jarque-Bera & 0.4507 & 3.4881 & 0.2588 & 2.3642 & 0.5705 & 1.8681 & 2.5471 \\
Probability & 0.7982 & 0.1748 & 0.8785 & 0.3066 & 0.7518 & 0.3929 & 0.2798 \\
\hline SOurce: Eviewny
\end{tabular}

Source: Eviews 11 Outputs.

Testing the stationarity of time series: It is worthy to note that testing the stationarity of time series should precede using the ARDL model to test the long-run relationship. The study used the augmented dickey-fuller (ADF) test; to test stationarity and ensure that all variables are integrated at level $[I(0)]$ or after taking the first difference $[I(1)]$ or a mixture of $[I(0)$ and I(1)]. Table (2) shows that all time series have a unit root at the $5 \%$ significance level. Since the absolute values of the calculated ADF test values are less than the critical values at the $5 \%$ significance level. We cannot therefore reject the null hypothesis that the time series have a unit root. However, all time series became stationary or integrated of the first order I(1), after taking the first difference, where the absolute values of calculated ADF test values are higher than the critical values at the $1 \%$ and $5 \%$ significance levels. These results support the rejection of the null hypothesis of a unit root, at the first difference. We can, therefore, use the ARDL to test the long-run relationship between the variables.

Table 2

The Augmented Dickey-Fuller test results

\begin{tabular}{cccccc}
\hline \multirow{2}{*}{ Variables At level } & \multicolumn{3}{c}{ After $1^{\text {st }}$ difference } & \multirow{2}{*}{ Significance level } \\
\cline { 2 - 5 } & Calculated values of ADF test & P-value & Calculated values of ADF test & P-value & $1 \%$ \\
Lfdi & -2.0075 & 0.2816 & -4.3490 & 0.0029 & $1 \%$ \\
Lgdppcgr & -1.9884 & 0.2893 & -4.2681 & 0.0035 & $5 \%$ \\
Linfra & -2.5879 & 0.1110 & -3.0832 & 0.0435 & $5 \%$ \\
Lrexc & -2.1422 & 0.2315 & -3.0347 & 0.0478 & $1 \%$ \\
Lcc & -2.3762 & 0.1593 & -5.4468 & 0.0003 & $5 \%$ \\
Lgovef & -2.0046 & 0.2827 & -3.6809 & 0.0131 & $5 \%$ \\
Lrq & -0.4127 & 0.8906 & -3.2984 & 0.0281 & 5 \\
\hline
\end{tabular}

\section{Empirical Results}

In this part, the study seeks to analyze the FDI function using the Cointegration approach "ARDL" and ECM. 


\subsection{Testing the Long-run Relationship Using the ARDL}

5.1.1. The optimal lag length Determination: As shown in table (3), all the criteria used to determine the optimal lag period indicate that the optimal lag period is one period.

\section{Table 3}

Optimal Lag Length

\begin{tabular}{cccccc}
\hline Lag & LR & FPE & AIC & SC & HQ \\
0 & NA & $1.63 \mathrm{e}-10$ & -2.670094 & -2.322944 & -2.588315 \\
1 & $140.7633^{*}$ & $7.71 \mathrm{e}-13^{*}$ & $-8.270069^{*}$ & $-5.492870^{*}$ & $-7.615844^{*}$ \\
\hline
\end{tabular}

Source: Eviews 11 Outputs.

5.1.2. Testing the long-run relationship using the Bounds Test: Considering the comparison between the calculated value of F-statistic and the critical upper and lower bounds at the 5\% significance level, Pesaran et al. (2001) distinguished between three different cases. (1) If the critical upper bound is lower than the calculated value of F-statistic, the null hypothesis that there is no longrun relationship can be rejected. (2) If the critical lower bound is higher than the calculated value of F-statistic, the null hypothesis that there is no long-run relationship can not be rejected. (3) If the calculated value of F-statistic lies between the critical lower and upper bounds, the decision to reject or accept the null hypothesis can not be taken. As shown in table (4), the calculated value of Fstatistic is 10.9 , which is above the critical upper bound at $1 \%, 5 \%$, and $10 \%$ significance levels. Therefore, the null hypothesis that the long-run relationship does not exist can be rejected. ${ }^{1}$ It should be noted that the critical values developed by Pesaran et al. (2001) are unlikely to be valid for small samples such as our sample, which is less than 30 annual observations. To overcome this obstacle, the study follows Akbota and Baek (2018), which covers only 23 years, and used the critical values introduced by Narayan (2005) for small samples. These critical values are for upper and lower bounds at 30 observations. In this context, table (4) shows that the calculated value of F-statistic is still higher than the upper bound at all levels of significance (1\%,5\%, and 10\%). This result strongly recommends that our F-tests seem robust, even in small samples, supporting the rejection of the null hypothesis (H0: $\beta 1=\beta 2=\beta 3=\beta 4=\beta 5=\beta 6=0)$ that there is no long-run relationship, and accepting the alternative hypothesis of existing a long-run relationship $(\mathrm{H} 1: \beta 1 \neq \beta 2 \neq \beta 3 \neq \beta 4 \neq \beta 5 \neq \beta 6 \neq 0$ ).

\section{Table 4}

Bounds Test results, for testing the long-run relationship between the variables included in the ARDL model

The value of $F$ statistic Critical bounds values (restricted constant and no trend)

$\begin{array}{cccc} & \text { significance } & \mathrm{I}(0) & \mathrm{I}(1) \\ 1 \% & 3.976 & 5.691 \\ 10.90 & 5 \% & 2.794 & 4.148 \\ & 10 \% & 2.334 & 3.515\end{array}$

Source: The value of the $\mathrm{F}$ statistic is from Eviews 11 Outputs.

- The critical values for upper and lower bounds obtained from Narayan, Paresh Kumar (2005). The Saving and Investment Nexus for China: Evidence from Cointegration Tests. Applied Economics, 37, p. 1987.

\footnotetext{
${ }^{1}$ Among the five cases of testing for long run relationship, introduced by (Pesaran et al., 2001), we used case 2 (restricted intercept and no trend) for the analysis. It is worthy to note that the critical values of the associated lower and upper bounds, at $1 \%, 5 \%$, and $10 \%$ significance levels, are $(2.88$, 3.99), (2.27, 3.28) and (1.99, and 2.94), respectively. (Pesaran et al., 2001: 300).
} 
5.1.3. Testing the model Stability: To test the stability of the long-run and short-run model coefficients, Pesaran and Shin (1999) suggested two tests "CUSUM \& CUSUM of Squares" (Institute of National Planning, 2018b). The charts (1 \& 2) show that the cumulative sum and the cumulative of squares values comes between the critical lines at the $5 \%$ significance level, which indicates the stability of the model's estimated coefficients and the residual variance over the time.

Chart (1): CUSUM test results

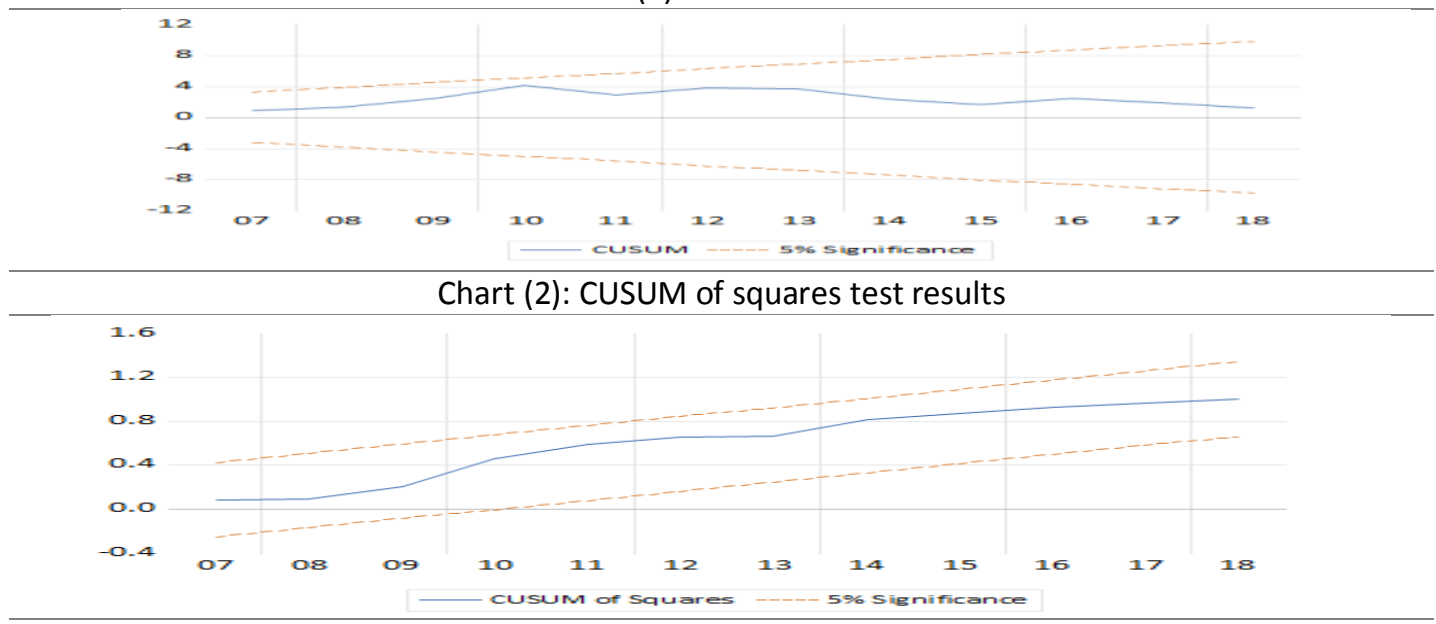

Source: Eviews 11 Outputs.

5.2. Interpreting the results of the long-run estimated coefficients: In the ARDL model estimates shown in table (5), R-squared is 0.92 , which shows that the model explains $92 \%$ variation in FDI to Egypt. In addition, the F-statistic is 15.95 , with a probability of 0.000022 , which shows that the results are statistically significant.

Table 5

The ARDL Model Estimations for the Long-run

\begin{tabular}{ccccc}
\hline Variable & Coefficient & Std. Error & t-Statistic & Prob. \\
\hline LFDI(-1) & 0.0989 & 0.1329 & 0.7439 & 0.4713 \\
LGDPPCGR & 0.9707 & 0.1738 & 5.5830 & 0.0001 \\
LINFRA & -0.2369 & 0.6449 & -3.3673 & 0.7197 \\
LREXC & -1.3498 & 0.4544 & -2.9703 & 0.0117 \\
LCC & 1.8664 & 1.6828 & 1.1091 & 0.2891 \\
LCC(-1) & -2.2877 & 1.2195 & -1.8759 & 0.0852 \\
LGOVEF & -3.8981 & 0.8957 & -4.3518 & 0.0009 \\
LRQ & 1.8544 & 0.7700 & 2.4082 & 0.0330 \\
LRQ(-1) & -0.8511 & 0.7392 & -1.1513 & 0.2720 \\
C & 0.9262 & 2.7482 & 0.3370 & 0.7419 \\
R-squared & 0.9228 & Mean dependent var & & 1.4115 \\
Adjusted R-squared & 0.8650 & S. D. dependent var & & 0.8115 \\
S. E. of regression & 0.2981 & Akaike info criterion & & 0.7204 \\
Sum squared resid & 1.0667 & Schwarz criterion & & 1.2164 \\
Log likelihood & 2.0745 & Hannan-Quinn criter. & & 0.8373 \\
F-statistic & 15.9553 & Durbin-Watson stat & & 2.2977 \\
Prob(F-statistic) & 0.000022 & & &
\end{tabular}

Source: Eviews 11 Outputs. 
Table (6) shows that gdppcgr (market size), rexc, govef, and rq "doing business environment" are statistically significant. The coefficients of gdppcgr and rq are positive, which implies that the FDI in Egypt is market-seeking and stimulated by the doing business environment. Meanwhile, rexc and govef coefficients are negative, which implies that the overvaluation of the Egyptian Pound and the quality of public and civil services have negatively affected the FDI in Egypt.

Table 6

Results of estimated long-run coefficients

\begin{tabular}{ccccc}
\hline Variables & Coefficient & Standard Error & t-statistic & p-value \\
\hline Igdppcgr & 1.0773 & 0.2212 & 4.8690 & 0.0004 \\
linfra & -2.2629 & 0.7233 & -0.3635 & 0.7225 \\
Irexc & -1.4980 & 0.5694 & -2.6305 & 0.0220 \\
Icc & -0.4674 & 2.3755 & -0.1967 & 0.8473 \\
Igovef & -4.3261 & 1.2199 & -3.5462 & 0.0040 \\
Irq & 1.1134 & 0.4465 & 2.4932 & 0.0283 \\
\hline
\end{tabular}

Source: Eviews 11 Outputs.

5.3. Interpreting the results of the short-run estimated coefficients: The Error Correction Model (ECM) was used to test the short-run relationship between the FDI flows to Egypt and related determinants for the period (1996-2018). Table (7) shows that the error correction term (ECT) is significant, and the coefficient of this error correction term is -0.90 , which indicates that $90 \%$ of the imbalances related to FDI flows to Egypt in one year will be adjusted in the next year. This table shows that both rq and $\mathrm{cc}$ are significant. The coefficients of these two variables are positive, which implies that the doing business environment and the control of corruption efforts stimulate FDI in Egypt in the short-run. The results shown in table (7) show that R-squared is 0.88 , which explores that the model explains $88 \%$ variation in FDI in Egypt in the short-run.

\section{Table 7}

short-run results

\begin{tabular}{ccccc}
\hline Variable & Coefficient & Std. Error & t-Statistic & Prob. \\
\hline $\mathrm{D}(\mathrm{LCC})$ & 1.8664 & 0.6850 & 2.7245 & 0.0185 \\
$\mathrm{D}(\mathrm{LRQ})$ & 1.8544 & 0.3836 & 4.8342 & 0.0004 \\
$\mathrm{ECT}(-1)$ & -0.9010 & 0.0766 & -11.7544 & 0.0000 \\
R-squared & 0.8816 & Mean dependent var & & 0.0401 \\
Adjusted R-squared & 0.8692 & S. D. dependent var & & 0.6551 \\
S. E. of regression & 0.2369 & Akaike info criterion & & 0.0841 \\
Sum squared resid & 1.0667 & Schwarz criterion & & 0.2329 \\
Log likelihood & 2.0745 & Hannan-Quinn criter. & & 0.1191 \\
Durbin-Watson stat & 2.2977 & & & \\
\hline
\end{tabular}

Source: Eviews 11 Outputs.

5.4. long-run and short-run impact coefficients: Table (8) shows that, in the long-run, both economic and institutional determinants affect FDI flows to Egypt. Institutional factors have a greater impact on FDI than economic ones. Increasing the market size and the Egyptian Pound against the US\$ by 1 percentage point, for each, lead to an increase and decrease of FDI to Egypt by 1.07 and 1.49 percentage points, respectively. Increasing the regulatory quality (enhancing the doing business environment) and decreasing the government effectiveness by 1 percentage point, for each, lead to an increase and decrease of FDI to Egypt by 11.1 and 4.3 percentage points, respectively. The results 
shown in table (8) show that, in the short-run, only the institutional determinants have an impact on FDI in Egypt. The impact of control of corruption and regulatory quality (doing business environment) on FDI in Egypt is almost equivalent and positive.

Table 8

long-run and short-run impact coefficients

\begin{tabular}{cccc}
\hline Variable & Long-run elasticities & Variable & short-run elasticities \\
\hline Lgdppcgr & 1.077 & $\mathrm{D}(\mathrm{Icc})$ & 1.866 \\
Lrexc & -1.498 & & \\
Lgovef & -4.326 & $\mathrm{D}(\mathrm{Irq})$ & 1.854 \\
Lrq & 11.101 & &
\end{tabular}

Source: long-run impact coefficients are calculated by the authors based on the results of table (6), and the short-run elasticities obtained from table (7).

\subsection{Diagnostic Tests to assess the quality and stability of the model}

The Breusch-Godfrey (LM) test results shown in table (9), imply that the probability value of F-statistic is insignificant at $1 \%, 5 \%$, and $10 \%$ levels of significance, supporting the acceptance of the null hypothesis that there is no serial correlation between the residuals of the estimated model. The Breusch-Pagan-Godfrey test for heteroscedasticity shown in table (9), shows that the probability of Fstatistic is 0.62 , which is insignificant at all levels of significance $(1 \%, 5 \%$, and $10 \%)$. This result supports the acceptance of the null hypothesis of homoscedasticity of the estimated model residuals.

\section{Table 9}

Breusch-Godfrey (LM Test) \& Breusch-Pagan-Godfrey results

\begin{tabular}{ccccc}
\hline Breusch-Godfrey (LM Test) & F statistic & 1.0626 & Prob. & 0.3247 \\
\cline { 2 - 4 } Breusch-Pagan-Godfrey & Obs* R-squared & 1.9381 & Prob. & 0.1639 \\
& F statistic & 0.8529 & Prob. & 0.6225 \\
& Obs* R-squared & 15.04 & Prob. & 0.5211
\end{tabular}

Source: Eviews 11 Outputs.

The chart (3), shows that the Jarque-Bera statistic is 0.80 , and the probability of this test is 0.66 , which implies the insignificance at all levels of significance (1\%, $5 \%$, and $10 \%)$. This result supports the acceptance of the null hypothesis of the normal distribution of the residuals.

Chart (3): Jarque-Bera test for normal distribution of the residuals
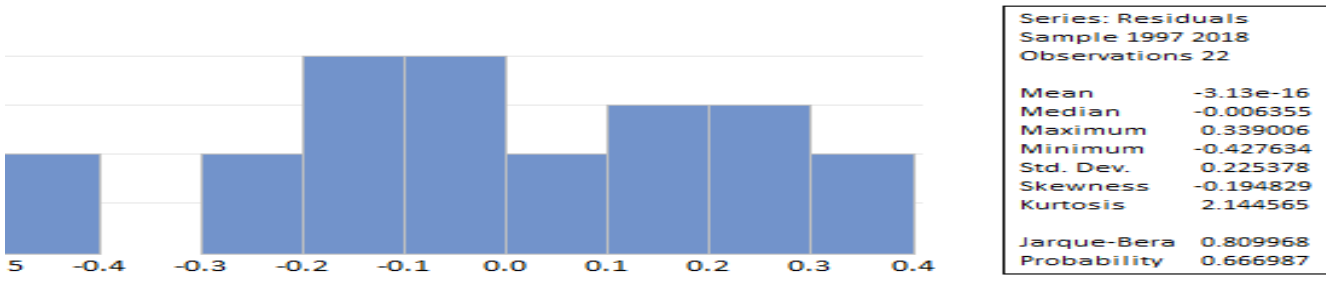

Source: Eviews 11 Outputs. 


\section{Conclusion}

This study explored the economic and institutional determinants of FDI in Egypt during the period (1996-2018). Based on the previous empirical research and the gap needed to be bridged. The study used a combination of economic and institutional factors that are expected to have an impact on FDI in Egypt. Results showed that, in the long-run, both economic and institutional factors influenced FDI in Egypt. While the market size and doing business environment stimulated FDI, the real exchange rate and government effectiveness discouraged FDI. The findings of the study imply that, in the short-run, only the institutional factors "control of corruption and doing business environment" have an impact on FDI in Egypt. Moreover, while the short-run impact coefficients are almost equivalent, these impact coefficients have exceeded those of the economic factors. Previous results shed light on the crucial role of institutional factors in creating a more attractive FDI environment in Egypt.

In addition, the study recommends the adoption of sound policies aimed at enhancing Egypt's attractiveness to FDI by reforming both economic and institutional environments. On the economic side, the state should benefit from the size of the Egyptian market and the floating local currency, and reduce crowding from the public sector to the private one in investment, in order to attract more FDI. On the institutional side, the state should enhance the quality of its institutions and pay close attention to governance issues (for instance, increasing the control of corruption, government effectiveness, and regulatory quality). Besides, improving the doing business environment is crucial for both domestic and foreign investors. In this context, far-reaching reforms need to be carried out in late-fields areas, such as trading across borders, enforcing contracts, paying taxes, registering property, starting a business, and resolving insolvency.

\section{References}

Adegboye, F.B., Osabohien, R., Olokoyo, F.O., Matthew, O., \& Adediran, O. (2020). Institutional quality, foreign direct investment, and economic development in sub-Saharan Africa. Humanities and Social Sciences Communications, 7(38). https://doi.org/10.1057/s41599-020-0529-x

Akbota, A., \& Baek, J. (2018). The environmental consequences of growth: empirical evidence from the Republic of Kazakhstan. Economies, (6)1, 1-11.

Akyüz, Y., \& Cornford, A. J. (2000). Capital flows to developing countries and the reform of the international financial system (Vol. 143). United Nations University, World Institute for Development Economics Research.

Asongu, S., Akpan, U.S. \& Isihak, S.R. (2018). Determinants of foreign direct investment in fastgrowing economies: evidence from the BRICS and MINT countries. Financial Innovation, 4(26). https://doi.org/10.1186/s40854-018-0114-0

Basyouny, M. N. (1986). The economic policy role towards foreign direct investments, with special study to the industrial sector in Egypt in light of "Infitah" policy. Unpublished Ph. D., Ain Shams University, Egypt.

Busse, M., \& Hefeker, C. (2007). Political risk, institutions and foreign direct investment. European journal of political economy, 23(2), 397-415.

Central Bank of Egypt (CBE). (2019). External Position of the Egyptian Economy FY 2019. No. 66. Egypt: CBE.

Central Bank of Egypt (CBE). Annual Report. 2014/15-2017/18. Egypt: CBE.

Charemza, W. W., \& Deadman, D. F. (2002). New directions in econometric practice: general to specific modelling, cointegration, and vector autoregression. (2nd Ed.). USA: Edward Elgar Publishing. 
Dunning, J. H. (1979). Explaining changing patterns of international production: in defence of the eclectic theory. Oxford Bulletin of Economics and Statistics, 41(4), 269-295.

Dunning, J. H. (1981). Explaining the international direct investment position of countries: towards a dynamic or developmental approach. Weltwirtschaftliches Archiv, 117, 30-64. doi.org/10.1007/BF02696577

Dunning, J. H., Lundan, S. M. (2008). Multinational enterprises and the global economy. (2nd ed.). UK: Edward Elgar.

Dunning, J. H., Rugman, A. M. (1985). The influence of Hymer's dissertation on the theory of foreign direct investment. The American Economic Review, 75(2), 228-232.

Elsayed, G. (2017). Corruption and foreign direct investment: an empirical study on Egypt. Journal of Development and Economic Policies, 19(2), 45-88.

Elshamy, H. (2017). The economic determinants of Chinese foreign direct investment in Egypt. In: Kim, YC. (ed.). China and Africa: a new paradigm of global business. (pp. 189-198). Switzerland: Palgrave Macmillan, Cham. https://doi.org/10.1007/978-3-319-47030-6_7

ElShazly, M. (2020). Determinants of foreign direct investment in developing countries: 1990-2017. Unpublished Master's thesis, the American University, Cairo.

Engle, R. F., \& Granger, C. W. J. (1987). Co-integration and error correction: representation, estimation, and testing. Econometrica, 55(2), 251-276.

Ghouse, G., Khan, S. A., \& Rehman, A. U. (2018). ARDL model as a remedy for spurious regression: problems, performance and prospects. Munich Personal RePEc Archive (MPRA), 83973. https://mpra.ub.uni-muenchen.de/83973/.

Hasan, A. A., \& Showman, A. H. (2013). The long-run equilibrium relationship analysis by using unit root tests and autoregressive distributed lag approach (ARDL). Journal of Economic Sciences, 9(34), 174-210.

Hassan, R. R. (2008). The impact of corruption on FDI in developing countries. Scientific Journal of Research and Commercial Studies, 22(2), 126-132.

Hosseini, H. (2005). An economic theory of FDI: a behavioral economics and historical approach. The Journal of Socio-Economics, 34(4), 528-541.

IMF. (2020). International financial statistics. https://data.imf.org/?sk=4C514D48-B6BA-49ED-8AB952B0C1A0179B_(accessed 04 June 2020)

Institute of National Planning. (2018a). The benefits and burdens of the external financing on Egypt. Planning and Development Issues Series, 306. Egypt: Institute of National Planning.

Institute of National Planning. (2018b). Exchange rate and its relationship with foreign investments in Egypt. Planning and Development Issues Series, 291. Egypt: Institute of National Planning.

Kahai, S. K. (2004). Traditional and non-traditional determinants of foreign direct investment in developing countries. Journal of Applied Business Research (JABR), 20(1), 43-50.

Kassem, A. Z. E., Awad, M. (2019). Determinants of foreign direct investment in Egypt's agriculture. Assiut Journal of Agricultural Sciences, 50(4). https://doi.org/10.21608/AJAS.2019.66207.

Khalek, Gouda. A. (1998). Egyptian economy and lessons of the Mexican crisis. L'Egypte Contemporaine, 89(449\&450), 5-41.

Markusen, J. R. (1998). Multinational enterprises and the theories of trade and location. In: Pontus, B., \& Ekholm, K. (eds.). The geography of multinational firms. (pp. 9-32). Springer, Boston, MA. https://doi.org/10.1007/978-1-4615-5675-6_2

Ministry of Economy and Foreign Trade. (2000). Foreign direct investment in Egypt and its economic expectations in the coming years. Egypt: Ministry of Economy and Foreign Trade. 
Mohamed, K. A. (2010). Foreign direct investment in Egypt: determinants, spillovers, and causality. Unpublished Ph. D., University of Leicester, UK.

Moosa, I. A. (2002). Foreign direct investment: theory, evidence and practice. New York: Palgrave.

Mottaleb, K. A. (2007). Determinants of foreign direct investment and its impact on economic growth in developing countries. MPRA, 9457, 1-15.

Narayan, P. K. (2005). The saving and investment nexus for China: evidence from cointegration tests. Applied economics, 37(17), 1979-1990.

Peres, M., Ameer, W., \& Xu, H. (2018). The impact of institutional quality on foreign direct investment inflows: evidence for developed and developing countries. Economic Research-Ekonomska Istraživanja, 31(1), 626-644. DOI: 10.1080/1331677X.2018.1438906.

Pesaran, M. H., Shin, Y., \& Smith, R. J. (2001). Bounds testing approaches to the analysis of level relationships. Journal of Applied Econometrics, 16, 289-326. DOI: 10.1002/jae.616

Rugman, A. M. (2006). Inside the multinationals 25th anniversary edition: the economics of internal markets. New York: Palgrave Macmillan.

Sabir, S., Rafique, A. \& Abbas, K. (2019). Institutions and FDI: evidence from developed and developing countries. Financial Innovation, 5(8). https://doi.org/10.1186/s40854-019-01237.

Shabana, O. Z. (1994). The FDI role in financing economic development in Egypt in light of market mechanisms. Paper presented at annual conference of Egyptian Society for Political Economy, Statistics, and Legislation, Cairo.

Shamoun, A. M. S. (2009). Global financial crisis and its impacts on the Egyptian economy. Scientific Journal of commerce Faculties, 4, 285-318.

UNCTAD. (2020). Foreign direct investment online database.https://unctadstat.unctad.org/wds/ ReportFolders/ reportFolders.aspx?sCS ChosenLang=en (accessed 04 June 2020)

Vernon, R. (1966). International investment and international trade in the product cycle. The Quarterly Journal of Economics, 80(2), 190-207.

World Bank. (2020). World Development Indicators. https://databank.worldbank.org/source/worlddevelopment-indicators (accessed 04 June 2020)

World Bank. (2020). Worldwide Governance Indicators. https://databank.worldbank.org/ source/worldwide-governance-indicators (accessed 04 June 2020)

Received: May 5, 2020

Revisions Received: Aug 22, 2020 


\section{Appendices}

Table (1): Empirical Studies focused on FDI Determinants in Developed and Developing Countries

\begin{tabular}{|c|c|c|c|c|c|}
\hline Author & $\begin{array}{l}\text { Adegboye et } \\
\text { al. (2020) }\end{array}$ & $\begin{array}{l}\text { ElShazly } \\
(2020)\end{array}$ & $\begin{array}{l}\text { Sabir et al. } \\
\text { (2019) }\end{array}$ & $\begin{array}{c}\text { Asongu et } \\
\text { al. } \\
(2018)\end{array}$ & $\begin{array}{l}\text { Peres et al. } \\
\quad(2018)\end{array}$ \\
\hline Sample Size & $\begin{array}{l}30 \text { Sub- } \\
\text { Saharan } \\
\text { African } \\
\text { Countries }\end{array}$ & $\begin{array}{l}\text { Top } 20 \text { FDI } \\
\text { host } \\
\text { Developing } \\
\text { countries }\end{array}$ & $\begin{array}{c}148 \text { Developed } \\
\text { \& Developing } \\
\text { Countries }\end{array}$ & $\begin{array}{l}9 \text { Developing } \\
\text { Countries }^{4}\end{array}$ & $\begin{array}{c}110 \\
\text { Developed \& } \\
\text { Developing } \\
\text { Countries }\end{array}$ \\
\hline Period & $(2000-2018)$ & (1990-2017) & (1996-2016) & $\begin{array}{l}(2001- \\
2011) \\
\end{array}$ & $(2002-2012)$ \\
\hline \multicolumn{6}{|l|}{$\begin{array}{c}\text { Economic } \\
\text { Determinants }\end{array}$} \\
\hline Market Size & - & $(+\mathrm{ve})$ & $(- \text { ve })^{1}$ & $(+\mathrm{ve})^{5}$ & $(+\mathrm{ve})^{2}$ \\
\hline Infrastructure & $(-\mathrm{ve})$ & $(+\mathrm{ve})$ & $(+\mathrm{ve})^{2}$ & $(+\mathrm{ve})^{5}$ & $(+\mathrm{ve})^{2}$ \\
\hline Openness & - & $(+\mathrm{ve})$ & $(+\mathrm{ve})^{2}$ & $(+\mathrm{ve})^{5}$ & - \\
\hline $\begin{array}{c}\text { Macroeconomic } \\
\text { Stability }\end{array}$ & - & - & $(- \text { ve })^{2}$ & - & - \\
\hline $\begin{array}{c}\text { Agriculture Value } \\
\text { Added }\end{array}$ & - & - & $(- \text { ve })^{1}$ & - & - \\
\hline Natural Resources & - & (+ve) & - & - & - \\
\hline $\begin{array}{c}\text { Private } \\
\text { Consumption }\end{array}$ & - & (+ve) & - & - & - \\
\hline Financial Crisis & - & - & - & - & $(-\mathrm{ve})^{2}$ \\
\hline \multicolumn{6}{|l|}{$\begin{array}{c}\text { Institutional } \\
\text { Determinants }\end{array}$} \\
\hline $\begin{array}{c}\text { Political Stability } \\
\text { and Absence of } \\
\text { Violence and/or } \\
\text { Terrorism }\end{array}$ & (+ve) & - & $(+\mathrm{ve})^{2}$ & - & - \\
\hline $\begin{array}{c}\text { Government } \\
\text { Effectiveness } \\
\text { (GOVEF) }\end{array}$ & - & - & $(+\mathrm{ve})^{2}$ & - & - \\
\hline $\begin{array}{c}\text { Control of } \\
\text { Corruption (CC) }\end{array}$ & - & - & $(+\mathrm{ve})^{2}$ & - & - \\
\hline Role of Law (RL) & - & - & $(+\mathrm{ve})^{3}$ & - & - \\
\hline $\begin{array}{c}\text { Voice \& } \\
\text { Accountability } \\
\text { (ACC) }\end{array}$ & $(-\mathrm{ve})$ & - & $(+v e)^{3}$ & - & - \\
\hline $\begin{array}{l}\text { Regulatory Quality } \\
\text { (RQ) }\end{array}$ & - & - & $(+\mathrm{ve})^{3}$ & - & - \\
\hline Governance (CC+ & - & - & - & - & $(+\mathrm{ve})^{3}$ \\
\hline
\end{tabular}


$\mathrm{RL})$

Source: This table was established in light of reviewing Literature, for example:

- Adegboye, F.B., Osabohien, R., Olokoyo, F.O., Matthew, O., \& Adediran, O. (2020). Institutional quality, foreign direct investment, and economic development in sub-Saharan Africa. Humanities and Social Sciences Communications, 7(38). https://doi.org/10.1057/s41599-020-0529-x

- ElShazly, M. (2020). Determinants of foreign direct investment in developing countries: 1990 - 2017. Unpublished Master's thesis, the American University, Cairo.

- Sabir, S., Rafique, A. \& Abbas, K. (2019). Institutions and FDI: evidence from developed and developing countries. Financial Innovation, 5(8). https://doi.org/10.1186/s40854-019-0123-7

- Asongu, S., Akpan, U.S. \& Isihak, S.R. (2018). Determinants of foreign direct investment in fastgrowing economies: evidence from the BRICS and MINT countries. Financial Innovation, 4(26). https://doi.org/10.1186/s40854-018-0114-0

- Peres, M., Ameer, W., \& Xu, H. (2018). The impact of institutional quality on foreign direct investment inflows: evidence for developed and developing countries. Economic ResearchEkonomska Istraživanja, 31(1), 626-644. DOI: 10.1080/1331677X.2018.1438906

1. The variable is statistically significant and affects FDI negatively in developed countries. In contrast, the variable is statistically significant and stimulates FDI in developing countries.

2. The variable is statistically significant for both developed and developing countries.

3. The variable is statistically significant for developed countries only.

4. BRICS (Brazil, Russia, India, China, South Africa), \& MINT (Mexico, Indonesia, Nigeria and Turkey) countries.

5. The variable is statistically significant for both BRICS \& MINT Countries.

Table (2): Empirical Studies focused on FDI Determinants in Egypt

\begin{tabular}{|c|c|c|c|c|}
\hline Author & $\begin{array}{c}\text { Kassem \& Awad } \\
\text { (2019) }\end{array}$ & $\begin{array}{c}\text { Institute of } \\
\text { National Planning } \\
(2018 b)\end{array}$ & $\begin{array}{l}\text { Elsayed } \\
(2017)\end{array}$ & $\begin{array}{c}\text { Elshamy } \\
\text { (2017) }\end{array}$ \\
\hline Sample Size & $\begin{array}{c}\text { Egypt, } \\
\text { Agricultural } \\
\text { Sector }\end{array}$ & Egypt & Egypt & $\begin{array}{c}\text { Egypt, } \\
\text { Chinese } \\
\text { FDI }\end{array}$ \\
\hline Period & \begin{tabular}{|c|} 
(July 2008-June \\
2018)
\end{tabular} & (1991-2016) & $\begin{array}{l}(1995- \\
2016)\end{array}$ & $\begin{array}{l}(1985- \\
2011)\end{array}$ \\
\hline \multicolumn{5}{|l|}{ Economic Determinants } \\
\hline Market Size & - & (+ve) & (+ve) & (+ve) \\
\hline Infrastructure & - & (+ve) & (+ve) & - \\
\hline Openness & - & (+ ve) & (+ ve) & - \\
\hline Exchange Rate & (- ve) & (- ve) & - & - \\
\hline Macroeconomic Stability & - & (- ve) & (-ve) & (- ve) \\
\hline Agriculture Value Added & (+ve) & - & - & - \\
\hline Interest Rate & (-ve) & - & - & - \\
\hline \begin{tabular}{|c|} 
Lending and discount given to economic \\
sectors
\end{tabular} & (+ ve) & - & - & - \\
\hline Main Agricultural Exports & (- ve) & - & - & - \\
\hline
\end{tabular}




\begin{tabular}{|c|c|c|c|c|}
\hline Main Agricultural Imports & (- ve) & - & - & - \\
\hline Natural Resources & - & - & - & (+ ve) \\
\hline $\begin{array}{c}\text { Institutional Determinants } \\
\begin{array}{c}\text { Political Stability and Absence of } \\
\text { Violence and/or Terrorism }\end{array}\end{array}$ & - & & & \\
\hline Government Effectiveness (GOVEF) & - & - & - & - \\
\hline Corruption & - & - & - & - \\
\hline Control of Corruption (CC) & - & - & - & - \\
\hline Role of Law (RL) & - & - & - & - \\
\hline Voice \& Accountability (ACC) & - & - & - & - \\
\hline Regulatory Quality (RQ) & - & - & - & - \\
\hline Governance (CC + RL) & - & - & - & - \\
\hline Government Policies & - & - & - & - \\
\hline Economic Freedom & - & - & (+ ve) & - \\
\hline Human Capital & - & - & (+ ve) & - \\
\hline
\end{tabular}

Source: This table was established in light of reviewing Literature, for example:

- Kassem, A. Z. E., Awad, M. (2019). Determinants of foreign direct investment in Egypt's agriculture. Assiut Journal of Agricultural Sciences, 50(4). https://doi.org/10.21608/AJAS.2019.66207

- Institute of National Planning. (2018b). Exchange rate and its relationship with foreign investments in Egypt. Planning and Development Issues Series, 291. Egypt: Institute of National Planning.

- Elsayed, G. (2017). Corruption and foreign direct investment: an empirical study on Egypt. Journal of Development and Economic Policies, 19(2), 45-88.

- Elshamy, H. (2017). The economic determinants of Chinese foreign direct investment in Egypt. In: Kim, YC. (ed.). China and Africa: a new paradigm of global business. (pp. 189-198). Switzerland: Palgrave Macmillan, Cham. https://doi.org/10.1007/978-3-319-47030-6_7 